UDC $004.932: 004.421 .4$

\title{
HISTOGRAM-BASED METHOD FOR NO-REFERENCE MEASUREMENT OF GENERALIZED CONTRAST OF COMPLEX IMAGES
}

\author{
Yuriy M. Romanyshyn, Elena S. Yelmanova \\ Institute of Telecommunications, Radioelectronics and Electronic Engineering \\ of Lviv Polytechnic National University, Lviv, Ukraine
}

\begin{abstract}
Background. Nowadays the task of automatically measuring of image quality in real time is extremely relevant for the vast majority of practical applications. No-reference quantitative assessment of image quality is one of the most pressing and difficult problems of image processing. Generalized contrast is the most important quantitative characteristic which determines the objective quality of the image. Currently, the development of new effective methods of no-reference measuring of generalized contrast for complex image in automatic mode with the level of computing costs, which are acceptable to implement the processing in real time, is one of the most urgent tasks of image preprocessing.

Objective. Development of new histogram-based method for no-reference measurement of generalized contrast of complex (multi-element) images based on the average contrast of image elements (objects and background) for different definitions of contrast kernel.

Methods. Analysis of known approaches to measurement of a local contrast of the image elements, of known methods of the quantitative assessment of generalized contrast of complex images as well as of the experimental research results for a series of complex real and test images allowed revealing inherent patterns (accordance to basic requirements to the definition of contrast, the nature and the dynamic of contrast changes at the linear transformations of the brightness scale), which are manifested depending on the use of the different definitions of the contrast kernels and the metrics of generalized contrast of images.
\end{abstract}

Results. No-reference contrast metrics for the histogram-based measuring of generalized contrast of complex images based on the average contrast of image elements for different definitions of contrast kernel is proposed.

Conclusions. Proposed no-reference metrics based on the average contrast of image elements for proposed contrast kernels allow providing accurate quantitative assessment (measurement) of generalized contrast of the real complex images and enable to evaluate (predict) with reasonable accuracy the perceived image quality at carrying out of subjective (qualitative) expert estimates.

Keywords: image quality; contrast metrics; no-reference; complex image; generalized contrast; contrast kernel; histogram.

\section{Introduction}

Currently, the development of effective techniques of image quality assessment (IQA) is one of the most urgent and important tasks of image preprocessing and analysis [1].

The ubiquity use of different types of mobile gadgets equipped with video sensors (photo and video cameras), the widespread using of unmanned vehicles of remote video controlled and automated robotic systems of various types, of destination and of basing (UAVs, copters, robotic cars, etc.), the wide applying of the space-based and airborne systems of remote sensing, surveillance and intelligence, the everywhere application of intelligent video systems for surveillance and monitoring, the rapid development and fast implementation of network technologies of collection, storage, transmission, processing and analysis of video data requires a operative assessment (in real time) of images quality for very large video streams (for the formed images) in automatic mode [2].

Quality of image is generally assessed using the appropriate metrics of image quality [3].

The main task of research in image quality metrics is to develop quantitative measures to enable to assess (predict) the perceived image quality [4].

Various metrics of image quality assessment are widely used for dynamic monitoring and adjusting image quality, for optimization of algorithms and parameter settings of image processing systems, etc [5].

At present the task of automatically measuring of image quality in real time is extremely relevant for the vast majority of practical applications [6].

Various approaches for image quality assessment are known [4]. Classification of image quality assessments in currently is most often based on two basic criteria.

Most often IQA techniques are categorized into subjective (qualitative) and objective (quantitative) 
methods [2].

Subjective (qualitative) assessments are based on expert evaluations that are performed in human beings (i.e. the image quality is evaluated by humans). Subjective assessments based on expert estimates are one of the most reliable ways of assessing the quality of images [7]. In practice, however, the subjective expert assessments are very expensive, too uncomfortable, time-consuming and therefore hardly used for the evaluation of image quality in an automatic mode, as well not usable in applications of real time [2].

Also, the subjective assessments are a very difficult for small changes in the image [5].

Objective IQA methods are carried out by measurement of objective quantitative characteristics of the image [8]. Currently objective IQA techniques are widely used for many tasks in various applications of image processing and analysis in automatic mode or real time.

Another approach to the classification of methods of image quality assessment is based on a criterion of presence (or the absence) of reference image.

Objective image quality metrics can be classified according to the availability of an initial distortion-free image which is to be compared to the distorted image.

Objective IQA methods (metrics) are classified as Full-Reference (FR), Reduced-Reference (RR) and NoReference (NR or Blind) methods depending on the availability of initial no-distorted image [2].

The initial (original) image and distorted (transformed) images are given (are considered) in FR IQA methods (metrics) [8]. The task is to provide the quality assessment of distorted (transformed) image. It is assumed here that initial distortion-free image has a "perfect" (absolute) quality. Full-reference IQA metrics (methods) are based on the measurement of the distance between the reference and distorted images. Fullreference image quality metrics are excellent for quality assessment in the coding-decoding, compression, transmission and reproduction, restore, fusion images, noise reduction and distortion compensation, and so on. However, full-reference IQA methods are generally not applicable for image enhancement since there perfect quality of enhanced image is not known a-priori.

In reduced reference IQA methods, the distorted image is given, and also the reference image is not available (or not fully available), however, partial information of the reference image is known [8]. Particular qualities based on its statistical, structural and texture properties of the reference image are employed for RR quality assessment of the distorted images.

The distorted image only is given in no-reference (or blind) IQA methods and the quality of the image is assessed without using of reference image [9].

IQA problem may seem difficult without knowledge of the reference image and the type of distortion. Noreference IQA is considered to be one of the most difficult problems in image analysis [1].

Currently, the development of effective methods of no-reference measuring of image quality in automatic mode that have the level of computing costs, which are acceptable to implement the processing in real time, is one of the most urgent tasks of image preprocessing [2].

In most of the existing NR IQA metrics it is assumed that the distortions which affect the image are known beforehand. Choice of IQA method (metric) of image quality assessment is usually carried out basing on the choice of the image processing method.

The objective quality of image is characterized by several basic parameters [10].

When considering the metrics of image quality should be noted that the generalized contrast is one of the principal components of image quality assessments.

Generalized contrast of image is the most important quantitative characteristic which determines the objective quality of the image, as well as the efficiency and the accuracy of its subsequent analysis and interpretation [11].

Currently task of no-reference measuring of generalized contrast for complex image is one of the most pressing problems in image quality assessment.

The task of no-reference measuring of generalized contrast for complex images based on global histogram is considered.

The paper deals with the problem of measurement of generalized contrast for complex images (Section 2). Known methods of quantitative assessments of a generalized contrast of complex images based on global histogram have been considered (Section 2).

In this paper, we propose a method for no-reference measuring of generalized contrast of complex images based on its histogram for different definitions of contrast kernel (Section 2).

The research of known and proposed definitions of a generalized contrast for different contrast kernels to evaluate the efficiency of formation of objective quantitative assessment of image contrast was carried out (Section 3). Experimental researches of the efficiency of the proposed and the several well-known no-reference methods of quantitative assessment of generalized contrast were carried out for a series of complex for real and test complex images (Section 3).

\section{Generalized contrast of complex images}

Currently quantitative measure of generalized contrast for complex (multi-element) images is not 
clearly defined. The generalized contrast of complex images is generally defined basing on the quantitative assessments of local contrast for individual pairs of image elements (objects and background). Local contrast of the image elements characterizes a quantitative difference between two elements of the image.

\section{A. Image element contrast and its definition}

It is traditionally supposed that the contrast definition has to meet the following basic requirements [12]. Contrast of two image elements (object and background) is a dimensionless function and characterizes the difference of values $L_{1}$ and $L_{2}$ of their brightness. Contrast of image elements must be an asymmetric function. The sign of contrast indicates which of the values predominates, $L_{1}$ or $L_{2}$. The maximum value of contrast module must correspond to maximum difference of the values $L_{1}$ or $L_{2}$ and must be equal to zero for equal values of $L_{1}$ and $L_{2}$.

It is usually assumed that the change of the absolute values of contrast is limited by the range $[0,1][13]$.

Bouger (1760) [14] showed that the difference threshold $\psi$ of lightness is proportional to initial value $L_{0}$ of brightness

$$
\psi=\frac{\Delta L}{L}=\frac{L_{1}-L_{0}}{L}
$$

A well-known metric is Weber contrast [15], which is a direct consequence of Weber's law (1834), where the viewer is assumed to be adapted to the background

$$
C^{W b}=\frac{\Delta L}{L_{b g}}=\frac{L_{b g}-L}{L_{b g}}=1-\frac{L}{L_{b g}}
$$

where $\Delta L$ is the increment or decrement in the target luminance from the uniform background luminance, $L$, $L_{b g}$ - the luminance of the object (target) and the background.

Definition of Weber is typically used for the measuring of the contrast of a single uniform object on a uniform background.

Similarly, King-Smith \& Kulikowski (1975) [16] have defined the local contrast from the uniform background as

$$
C^{K}=\frac{\Delta L}{L_{b g}}=\frac{L_{p k}-L_{b g}}{L_{b g}}
$$

where $L_{p k}, L_{b g}$ - values of the peak luminance and the average luminance.

Burkhardt \& Gottesman (1984) [17] have proposed the following definition of the local contrast for the uniform background

$$
C^{B G}=\frac{\Delta L}{L_{0}}=\frac{L_{p k}-L_{b g}}{L_{0}}
$$

where $L_{0}$-adaptation level:

$$
L_{0}= \begin{cases}L_{b g}, & \text { if } \Delta L>0 \\ L_{p k}, & \text { if } \Delta L<0\end{cases}
$$

Whittle (1986) [18] has proposed the contrast definition as the ratio of the value of luminance increment to minimum luminance $L_{\min }$

$$
C^{W h}=\Delta L / L_{\min }
$$

Sanders and McCormick (1993) [19] have proposed the contrast definition as the ratio of the value of luminance increment to maximum luminance Lmax

$$
C^{S M}=\Delta L / L_{\max }
$$

Definitions (1) - (7) are the measures of the contrast for the simple images of a single uniform target (object) on a uniform background and are ineffective for the measuring of local contrast of elements (objects and background) of complex images with a large number of objects. Significant disadvantage of definitions (1) - (6) is an unlimited range of possible contrast values [20].

Nesteruk \& Porfirieva (1970) [21] have proposed the law of visual light sensation

$$
\sigma_{i j}=\frac{L_{i}^{2 \gamma}-L_{j}^{2 \gamma}}{L_{i}^{2 \gamma}+L_{j}^{2 \gamma}}
$$

where $\sigma_{i j}$ - reduced (normalized) signal of sensation, $L_{i}, L_{j}$ - luminance values of image elements.

Nesteruk \& Porfirieva proposed a definition of the weighted contrast for two elements of a complex image for adaptation level $L_{0}$

$$
C^{N}\left(L_{i}, L_{j}\right)=C_{i j 0}=\frac{C_{i 0}+C_{j 0}}{1+C_{i 0} \cdot C_{j 0}}
$$

where

$$
C_{i 0}=\frac{L_{i}-L_{0}}{L_{i}+L_{0}}, C_{j 0}=\frac{L_{j}-L_{0}}{L_{j}+L_{0}}
$$

Most often the value $L_{0}$ of adaptation level is assumed to equal of the average brightness value of current image, $L_{0}=\bar{L}=\operatorname{mean}(L)$. 
In this case, the expression (9) can be represented as follows

$$
C^{N}\left(L_{1}, L_{2}\right)=\frac{L_{1} \cdot L_{2}-\bar{L}^{2}}{L_{1} \cdot L_{2}+\bar{L}^{2}}
$$

where $\bar{L}$ - the average value of the elements brightness of the current image.

The most extensive practical use currently has the following definition of weighted contrast for elements of complex images [6]

$$
C^{w t}\left(L_{1}, L_{2}\right)=\frac{L_{1}-L_{2}}{L_{1}+L_{2}}
$$

In [22] the definitions of a relative contrast of elements of complex images have been considered

$$
\begin{gathered}
C^{r e l_{1}}\left(L_{1}, L_{2}\right)=\frac{L_{1}-L_{2}}{\max \left(L_{1}, L_{2}\right)} \\
C^{r e l_{2}}\left(L_{1}, L_{2}\right)=\frac{L_{1}-L_{2}}{1-\min \left(L_{1}, L_{2}\right)}
\end{gathered}
$$

The main disadvantage of contrast definition (10)(13) is the uncertainty and the multiplicity of the conditions under which the extreme values of weighted contrast are achieved [20].

In [20] Vorobel (1999) has offered the linear definition of the absolute contrast of image elements which provides performance of the basic (discussed earlier) requirements to the definition of contrast:

$$
C^{V}\left(L_{i}, L_{j}\right)=\frac{L_{i}-L_{j}}{L M A X}
$$

where LMAX - maximum possible brightness, $L M A X=1$.

In [12] Vorobel\&Beregulyak (2007) have proposed a generalized definition for absolute contrast (where $\mathrm{n}>0$ ):

$$
C^{V B}\left(L_{1}, L_{2}\right)=\operatorname{sign}\left(L_{1}^{n}-L_{2}^{n}\right) \cdot|| L_{1}^{n}-\left.L_{2}^{n}\right|^{1 / n} \mid
$$

In [23] it has been shown that the linear definition of contrast, which satisfies the conditions of asymmetry and equivalence of impact of the arguments, of unambiguity and certainty of the conditions under which the equality to zero and the extreme values of contrast are achieved, and which is invariant to the linear transformations of the brightness scale, has the form

$$
C^{Y}\left(L_{i}, L_{j}\right)=\frac{L_{i}-L_{j}}{L_{\max }-L_{\min }}
$$

where $L_{\min }, L_{\max }$ - minimum and maximum brightness values of elements of the current image.

The definitions (10)-(16) of the contrast of image elements are called the contrast kernels and are used for measuring the generalized contrast of complex images.

\section{B. Definition of generalized contrast of complex image}

The vast majority of real images have complex the structural nature. Generalized contrast of complex images is generally determined based on quantitative assessments of contrast for the individual pairs of image elements (objects and background) [3].

In [24] Haralick (1973) has proposed the contrast definition for texture image

$$
C_{\text {Har }}=\sum_{(n, m)}\left(L_{n}-L_{m}\right)^{2} \cdot h\left(L_{n}, L_{m}\right)
$$

where $h\left(L_{n}, L_{m}\right)$ - normalized spatial dependence matrix for $\mathrm{n}$ and $\mathrm{m}$ image elements.

In [25] Haralick (1979) has offered generalized definition of contrast for texture image (where $\mathrm{k}>0$ )

$$
C_{\text {Har }}^{\prime}=\sum_{(n, m)}\left|L_{n}-L_{m}\right|^{k} \cdot h\left(L_{n}, L_{m}\right)
$$

In [21] Nesteruk \& Porfirieva (1970) proposed to the definition of the generalized contrast for anisotropic images on the base of the weighted contrast $C^{N}(8)$ :

$$
C_{g e n}^{N}=\int_{0}^{1}\left|\frac{L^{2}-L_{0}^{2}}{L^{2}+L_{0}^{2}}\right| \cdot p(L) d L
$$

where $p(L)$ - density distribution of image brightness.

To address the shortcomings specific to definitions (2) and (3) of weighted contrast, Vorobel (1999) has proposed the definition of generalized contrast on the base of the absolute contrast $C^{V}$ (14) [20]:

$$
C_{\text {gen }}^{V}=\int_{0}^{1}\left|\frac{\left(L-L_{0}\right)}{L M A X}+\frac{1}{2}-\right| \frac{\left(L-L_{0}\right)}{L M A X}-\frac{1}{2}|| \cdot p(L) d L
$$

In [12] Vorobel and Beregulyak (2007) have proposed the generalized definition of the contrast for complex image

$$
C_{g e n}^{V B}=\frac{1}{2} \int_{0}^{L M A X}\left\|\sqrt[n]{2 \mid\left(L^{n}-L_{0}^{n}\right)}||+1-\right\| \sqrt[n]{2 \mid\left(L^{n}-L_{0}^{n}\right)}|-1| \mid p(L) d L
$$


In the case when all image elements are considered equivalent, a generalized contrast of complex image is most often defined as the average value of absolute contrasts of all pairs of image elements:

$$
C_{\text {avg }}=\int_{0}^{1} \int_{0}^{1}\left|C\left(L_{1}, L_{2}\right)\right| \cdot p\left(L_{1}, L_{2}\right) d L_{1} d L_{2}
$$

where $C\left(L_{1}, L_{2}\right)$ - local contrast of pairs image elements, $p\left(L_{1}, L_{2}\right)$ - density distribution of brightness for pairs of image elements.

Expression (22) requires the solution of the problem of determining the boundaries of image elements (objects and background), which in itself is a challenge [6].

Suppose that the current image consists of a finite number of equivalent elements (objects and background) which do not influence on each other (which are independent from each other).

For the case where image elements are independent events relatively to each other (22)

$$
C_{\text {avg }}^{*}=\int_{0}^{1} \int_{0}^{1}\left|C\left(L_{1}, L_{2}\right)\right| \cdot p\left(L_{1}\right) \cdot p\left(L_{2}\right) d L_{1} d L_{2}
$$

In this case the average generalized contrast (23) of complex images for contrast kernels (10), (17), (11) and (14)-(16) can be defined as follows:

$$
\begin{aligned}
C_{a v g}^{N} & =\int_{0}^{1} \int_{0}^{1}\left|\frac{L_{1} \cdot L_{2}-\bar{L}^{2}}{L_{1} \cdot L_{2}+\bar{L}^{2}}\right| \cdot p\left(L_{1}\right) \cdot p\left(L_{2}\right) d L_{1} d L_{2} \\
C_{a v g}^{H a r} & =\frac{1}{2} \cdot \int_{0}^{1} \int_{0}^{1}\left(L_{1}-L_{2}\right)^{2} \cdot p\left(L_{1}\right) \cdot p\left(L_{2}\right) d L_{1} d L_{2} \\
C_{a v g}^{w t} & =\int_{0}^{1} \int_{0}^{1}\left|\frac{L_{1}-L_{2}}{L_{1}+L_{2}}\right| \cdot p\left(L_{1}\right) \cdot p\left(L_{2}\right) d L_{1} d L_{2} \\
C_{a v g}^{V} & =\int_{0}^{1} \int_{0}^{1} \mid \frac{\left|L_{1}-L_{2}\right|}{L M A X} \cdot p\left(L_{1}\right) \cdot p\left(L_{2}\right) d L_{1} d L_{2} \\
C_{a v g}^{V B} & =\int_{0}^{1} \int_{0}^{1}|| L_{1}^{n}-\left.L_{2}^{n}\right|^{1 / n} \mid \cdot p\left(L_{1}\right) \cdot p\left(L_{2}\right) d L_{1} d L_{2} \\
C_{a v g}^{Y} & =\int_{0}^{1} \int_{0}^{1}\left|\frac{L_{1}-L_{2}}{L_{\max }-L_{\min }}\right| \cdot p\left(L_{1}\right) \cdot p\left(L_{2}\right) d L_{1} d L_{2}
\end{aligned}
$$

The known (19)-(21) and the proposed (24)-(29) definitions are the contrast metrics for the quantitative assessment (for the measuring) of the generalized contrast of complex images.

Comparative analysis of the known and the proposed definitions of generalized contrast were carried out in Section 3.

\section{Experimental research}

\section{A. The methodic of the research}

Experimental researches were carried out by comparative analysis of the values of quantitative assessments of generalized image contrast for the three groups of images (A1-A9, B1-B9 and D-N).

Formation of sequences of test images for the first two groups (A1-A9) and (B1-B9) has been conducted by linear transformations of the following type

$$
L^{\prime}=k^{i} \cdot L+b^{i},
$$

in which the brightness range $\left[L_{\min }, L_{\max }\right]$ of reference images $\mathrm{A}$ and $\mathrm{B}$ was converted into a range $\left[L_{\min }^{i}, L_{\max }^{i}\right]$ of $i$-th test image, where the values of coefficients $k_{i}$ and $b_{i}$ of the transformation for $i$-th test image are the following:

$$
\begin{gathered}
k^{i}=\frac{L_{\text {max }}^{i}-L_{\min }^{i}}{L_{\text {max }}-L_{\text {min }}} \\
b^{i}=\frac{L_{\text {min }}^{i} \cdot L_{\text {max }}-L_{\text {min }} \cdot L_{\text {max }}^{i}}{L_{\text {max }}-L_{\text {min }}}
\end{gathered}
$$

where $L_{\min }, L_{\max }$ - minimum and maximum values of brightness of the base image, $L_{\min }^{i}, L_{\max }^{i}-$ minimum and maximum brightness values of $i$-th test image.

Table 1 shows the minimum and maximum brightness values for the test images of first two groups formed by linear transformation of the form (30)-(31) of the reference image A and B.

Table 1. Extreme brightness values of the test images

\begin{tabular}{|l|c|c|c|c|c|c|c|c|c|}
\hline$i$ & 1 & 2 & 3 & 4 & 5 & 6 & 7 & 8 & 9 \\
\hline$L_{\min }^{i}$ & 0.00 & 0.30 & 0.60 & 0.00 & 0.20 & 0.40 & 0.00 & 0.20 & 0.00 \\
\hline$L_{\max }^{i}$ & 0.40 & 0.70 & 1.00 & 0.60 & 0.80 & 1.00 & 0.80 & 1.00 & 1.00 \\
\hline
\end{tabular}

Appearance of the reference image A for formation of test images A1-A9 of the first group is shown in Fig. 1. 


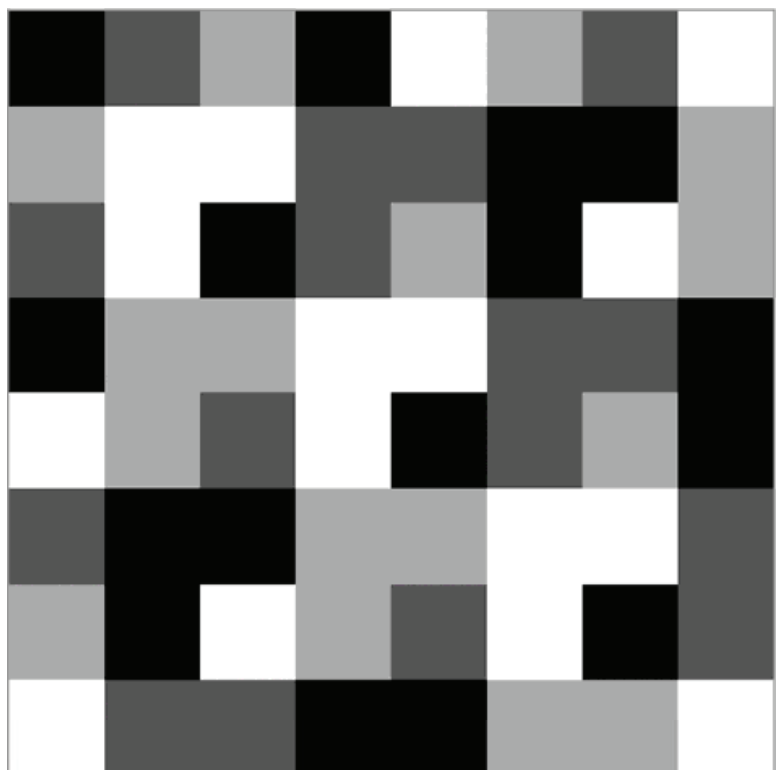

a)

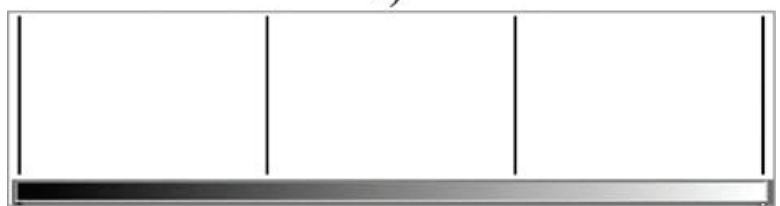

b)

Fig.1. Reference test image a) and its histogram b).

Appearance of the test images A1-A9 of the first group are shown in Fig.2.
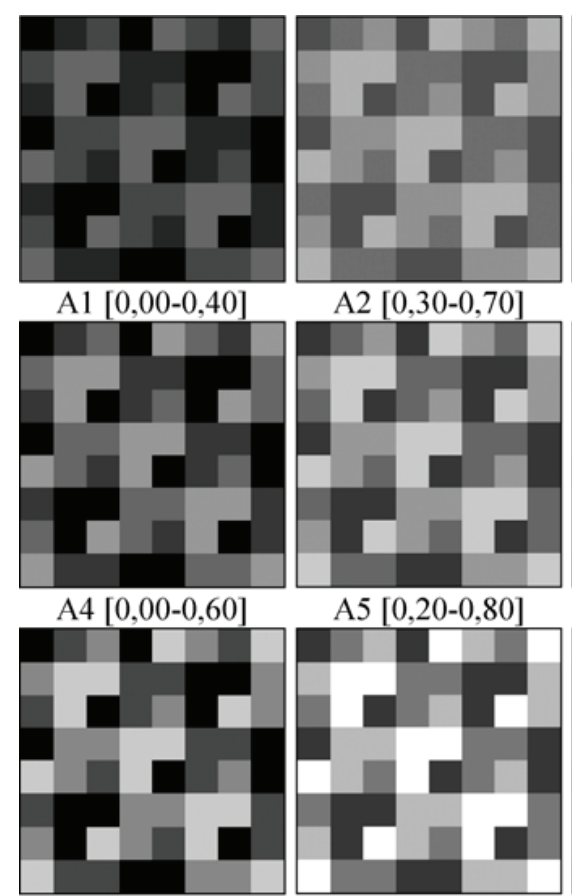

A7 [0,00-0,80]

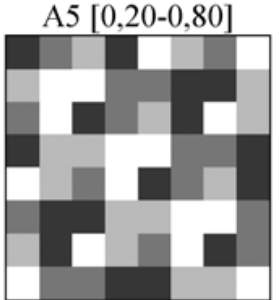

A8 $[0,20-1,00]$

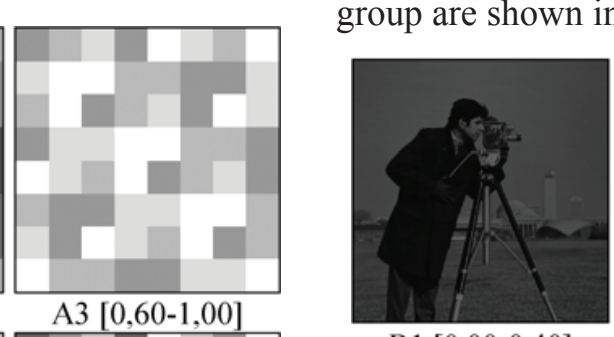

B1 $[0,00-0,40]$

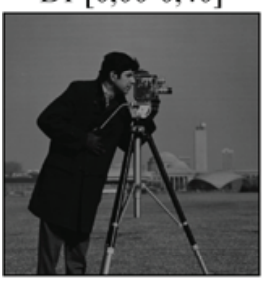

B4 $[0,00-0,60]$

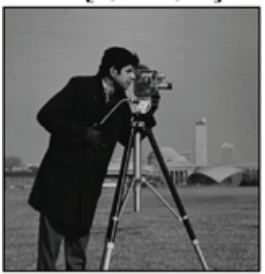

B7 $[0,00-0,80]$
Appearance of the reference image B [26] for formation of test images B1-B9 is shown in Fig.3.

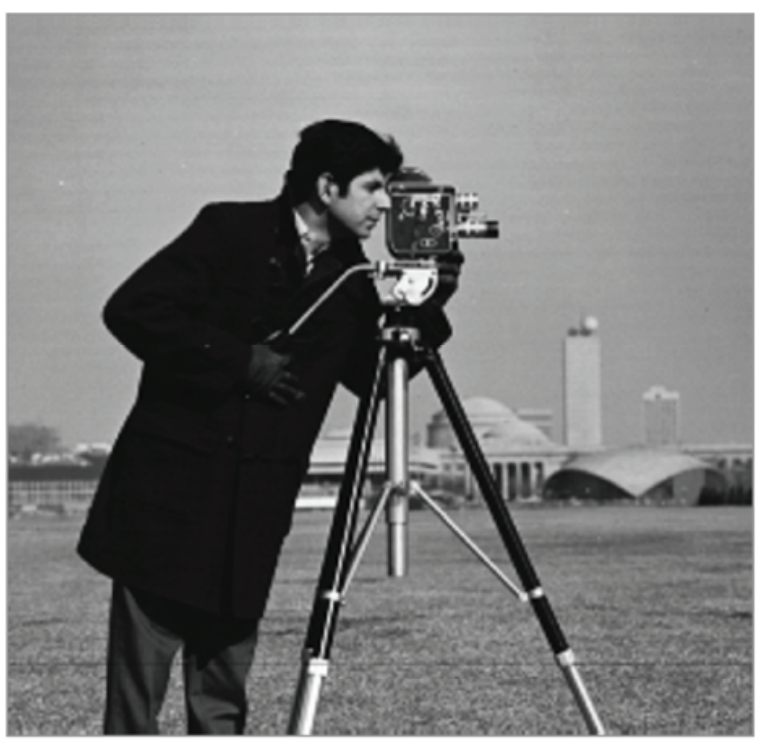

a)

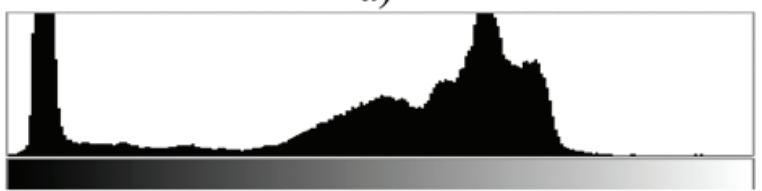

b)
Fig.3. Reference test image B a) and its histogram b). Appearance of the test images B1-B9 of the second group are shown in Fig. 4.

Fig.4. Test images B1-B9 of the second group.

Fig.2. Test images A1-A9 of the first group.

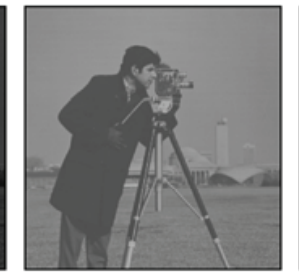

B2 [0,30-0,70]

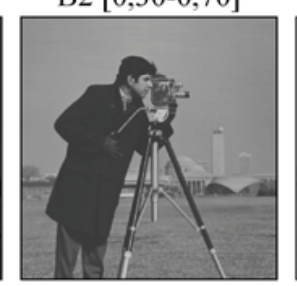

B5 $[0,20-0,80]$

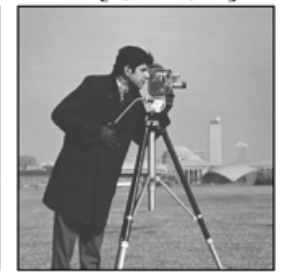

B8 [0,20-1,00]

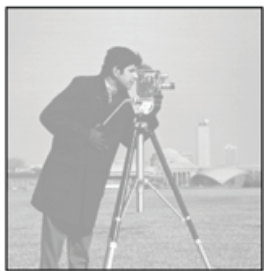

B3 $[0,60-1,00]$

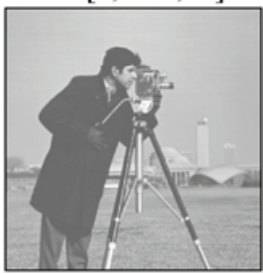

B6 [0,40-1,00]

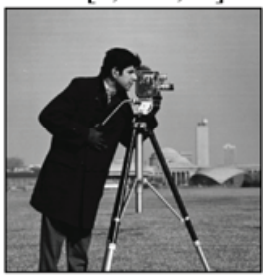

B9 $[0,00-1,00]$ 
The third group of the test images consists of standard test images (D-N) with complex structural nature [26]. Appearance of the test images D-N of the third group are shown in Fig.5.

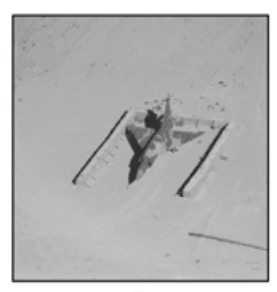

D

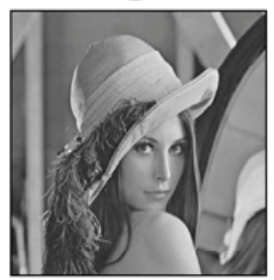

G

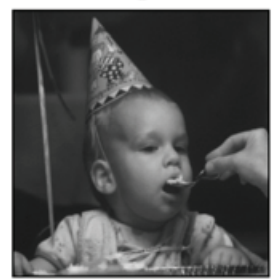

$\mathrm{L}$

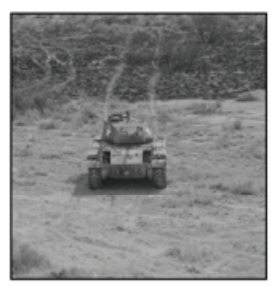

E

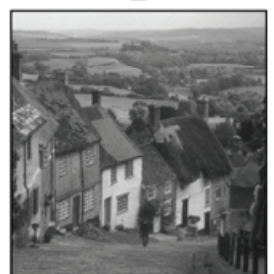

$\mathrm{H}$

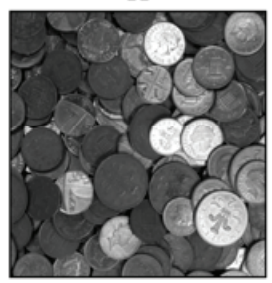

$\mathrm{M}$

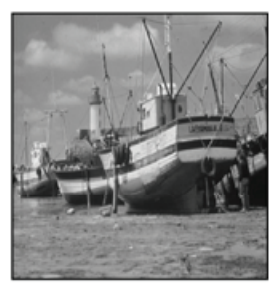

F

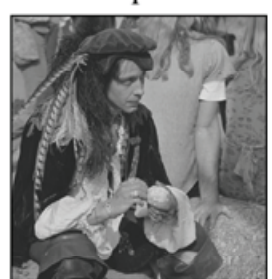

K

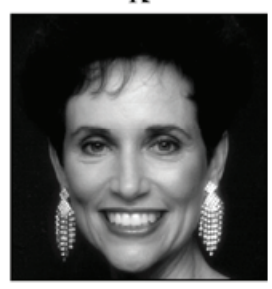

$\mathrm{N}$
Fig.5. Test images of the third group.

\section{$B$. The measurement results}

Measurements for generalized contrast of (19)-(21) and for the averaged contrast of (24)-(29) to provide the quantitative assessment of generalized contrast for test images were held.

Results of calculating the generalized contrast for test images are shown in Table 2, Table 3 and Table 4.

Table 2. Result of calculating for test images A1-A9

\begin{tabular}{|c|c|c|c|c|c|c|c|c|c|}
\hline & A1 & A2 & A3 & A4 & A5 & A6 & A7 & A8 & A9 \\
\hline$L_{\min }^{A_{i}}$ & 0.00 & 0.30 & 0.60 & 0.00 & 0.20 & 0.40 & 0.00 & 0.20 & 0.00 \\
\hline$L_{\max }^{A_{i}}$ & 0.40 & 0.70 & 1.00 & 0.60 & 0.80 & 1.00 & 0.80 & 1.00 & 1.00 \\
\hline$C_{g e n}^{N}$ & 0.566 & 0.267 & 0.167 & 0.566 & 0.391 & 0.284 & 0.566 & 0.429 & 0.566 \\
\hline$C_{g e n}^{V}$ & 0.267 & 0.269 & 0.267 & 0.400 & 0.400 & 0.400 & 0.533 & 0.533 & $0.667 \mid$ \\
\hline $\begin{array}{l}C_{g e n}^{V / B} \\
\end{array}$ & 0.286 & 0.355 & 0.388 & 0.429 & 0.486 & $0.521 \mid$ & 0.572 & 0.633 & 0.683 \\
\hline$C_{\text {avg }}^{N}$ & 0.599 & 0.182 & 0.109 & 0.599 & 0.291 & 0.197 & 0.59 & 0.331 & 0.599 \\
\hline$C_{a v g}^{H a r}$ & 0.044 & 0.045 & 0.044 & 0.100 & 0.100 & $0.100 \mid$ & 0.178 & 0.178 & 0.278 \\
\hline$C_{\text {avg }}^{w t}$ & 0.504 & 0.170 & 0.105 & 0.504 & 0.264 & 0.183 & 0.504 & 0.297 & 0.504 \\
\hline$C_{\text {avg }}^{V}$ & 0.167 & 0.167 & $0.167 \mid$ & 0.250 & 0.250 & 0.250 & 0.333 & 0.333 & 0.417 \\
\hline$C_{\text {avg }}^{V B}$ & 0.185 & 0.231 & 0.253 & 0.278 & 0.316 & 0.340 & 0.370 & 0.412 & 0.463 \\
\hline$C_{\text {avg }}^{Y}$ & 0.417 & .418 & 0.417 & 0.417 & 0.417 & 0.417 & 0.417 & 0.417 & 0.417 \\
\hline
\end{tabular}

Table 3. Result of calculating for test images B1-B9

\begin{tabular}{|c|c|c|c|c|c|c|c|c|c|}
\hline & B1 & B2 & B3 & B4 & B5 & B6 & B7 & B8 & B9 \\
\hline$\frac{L_{\min }^{B_{i}}}{.}$ & 0.00 & 0.30 & 0.60 & 0.00 & 0.20 & 0.40 & 0.00 & 0.20 & 0.00 \\
\hline$\frac{L_{\max }^{B_{i}}}{x}$ & 0.40 & 0.70 & 1.00 & 0.60 & 0.80 & 1.00 & 0.80 & 1.00 & 1.00 \\
\hline$C_{g e n}^{N}$ & 0.422 & 0.174 & 0.107 & 0.422 & 0.266 & 0.187 & 0.422 & 0.296 & 0.422 \\
\hline \begin{tabular}{l|}
$C_{g e n}^{V}$ \\
\end{tabular} & 0.164 & 0.164 & 0.164 & 0.246 & 0.246 & 0.246 & 0.328 & 0.328 & 0.410 \\
\hline$C_{g e n}^{V B}$ & 0.187 & 0.233 & 0.257 & 0.281 & 0.319 & 0.344 & 0.375 & 0.416 & 0.468 \\
\hline $\bar{C}_{\text {avg }}^{N}$ & 0.441 & 0.133 & 0.070 & 0.441 & 0.215 & 0.144 & 0.441 & 0.246 & 0.441 \\
\hline$C_{a v g}^{H a r}$ & 0.019 & 0.019 & 0.019 & 0.043 & 0.043 & 0.043 & 0.076 & 0.076 & 0.118 \\
\hline \begin{tabular}{ll|}
$C_{\text {avg }}^{w t}$ \\
\end{tabular} & 0.367 & 0.116 & 0.079 & 0.368 & 0.185 & 0.125 & 0.368 & 0.210 & 0.368 \\
\hline$C_{\text {avg }}^{V}$ & 0.105 & 0.105 & 0.105 & 0.158 & 0.158 & 0.158 & 0.211 & 0.211 & 0.263 \\
\hline$C_{\text {avg }}^{V B}$ & 0.126 & 0.158 & 0.175 & 0.189 & 0.217 & 0.234 & 0.252 & 0.281 & 0.315 \\
\hline \begin{tabular}{c|}
$C_{a v g}^{Y}$ \\
\end{tabular} & 0.263 & 0.263 & 0.263 & 0.263 & 0.263 & 0.263 & 0.263 & 0.263 & 0.263 \\
\hline
\end{tabular}

Table 4. Result of calculating for test images D-N

\begin{tabular}{|c|c|c|c|c|c|c|c|c|c|}
\hline & D & E & $F$ & G & $\mathrm{H}$ & $\mathrm{K}$ & $\mathrm{M}$ & E & $\mathrm{N}$ \\
\hline$C_{g e n}^{N}$ & 0.068 & 0.250 & 0.278 & 0.316 & 0.325 & 0.363 & 0.510 & 0.408 & 0.802 \\
\hline$\overline{C_{g e n}^{V}}$ & 0.089 & .243 & 0.281 & 0.312 & 0.304 & 0.323 & 0.314 & 0.33 & 0.504 \\
\hline$C_{g e n}^{V B}$ & 0.141 & 0.322 & 0.350 & $0.387 \mid$ & 0.370 & 0.394 & 0.356 & $0.387 \mid$ & 0.496 \\
\hline \begin{tabular}{l|}
$C_{\text {avg }}^{N}$ \\
\end{tabular} & 0.062 & .186 & 0.257 & 0.249 & 0.253 & 0.278 & 0.362 & 0.32 & 0.811 \\
\hline $\begin{array}{l}C_{\text {avg }} \\
\text { arr }\end{array}$ & 0.015 & 0.040 & 0.067 & 0.070 & 0.075 & 0.070 & 0.070 & $0.097 \mid$ & 0.168 \\
\hline$C_{a v g}^{w t}$ & 0.057 & 0.176 & 0.232 & 0.238 & 0.246 & 0.262 & 0.323 & 0.311 & 0.698 \\
\hline \begin{tabular}{l|l}
$C_{\text {avg }}^{V}$ \\
\end{tabular} & 0.067 & 0.159 & 0.196 & 0.215 & 0.215 & 0.215 & 0.198 & 0.235 & 0.307 \\
\hline \begin{tabular}{l|}
$C_{\text {avg }}^{V B}$ \\
\end{tabular} & 0.111 & 0.224 & 0.258 & 0.286 & 0.283 & 0.279 & 0.241 & 0.292 & 0.327 \\
\hline \begin{tabular}{c|}
$C^{Y}$ \\
\end{tabular} & 0.068 & 176 & $\overline{196}$ & 0249 & 0.244 & 0267 & 0.216 & 10235 & 0.307 \\
\hline
\end{tabular}

Graphs of the values of generalized contrast (Table 2) for the test images A1-A9 (Fig.2) are shown in Fig.6.

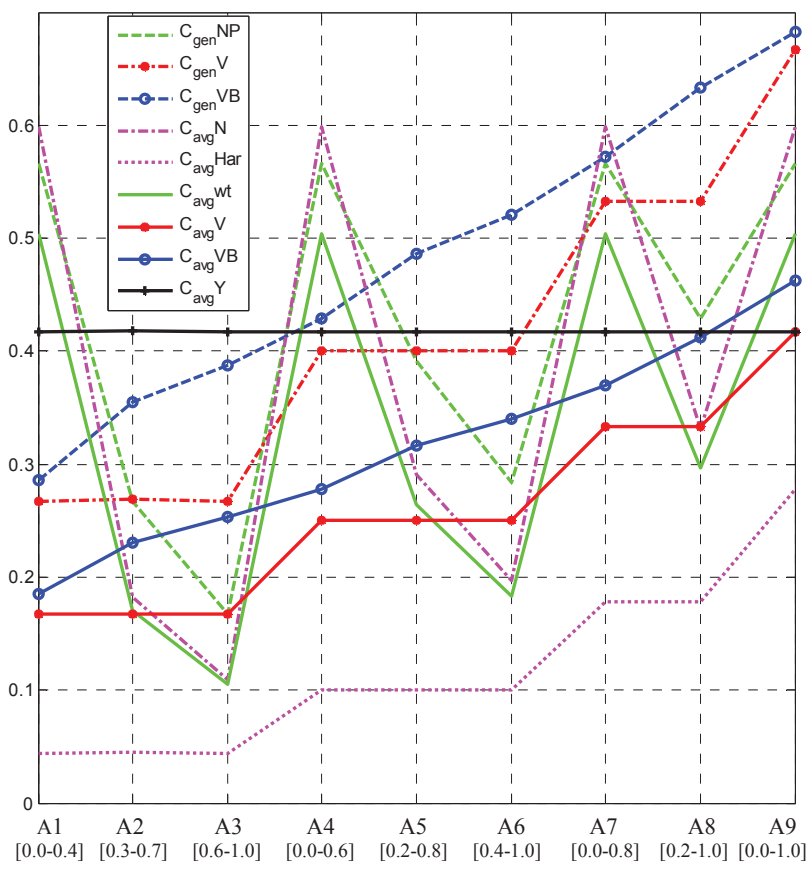

Fig.6. Quantitative assessments for test images A1-A9 
Graphs of the values of generalized contrast (Table 3) for the test images B1-B9 (Fig.4) are shown in Fig.7.

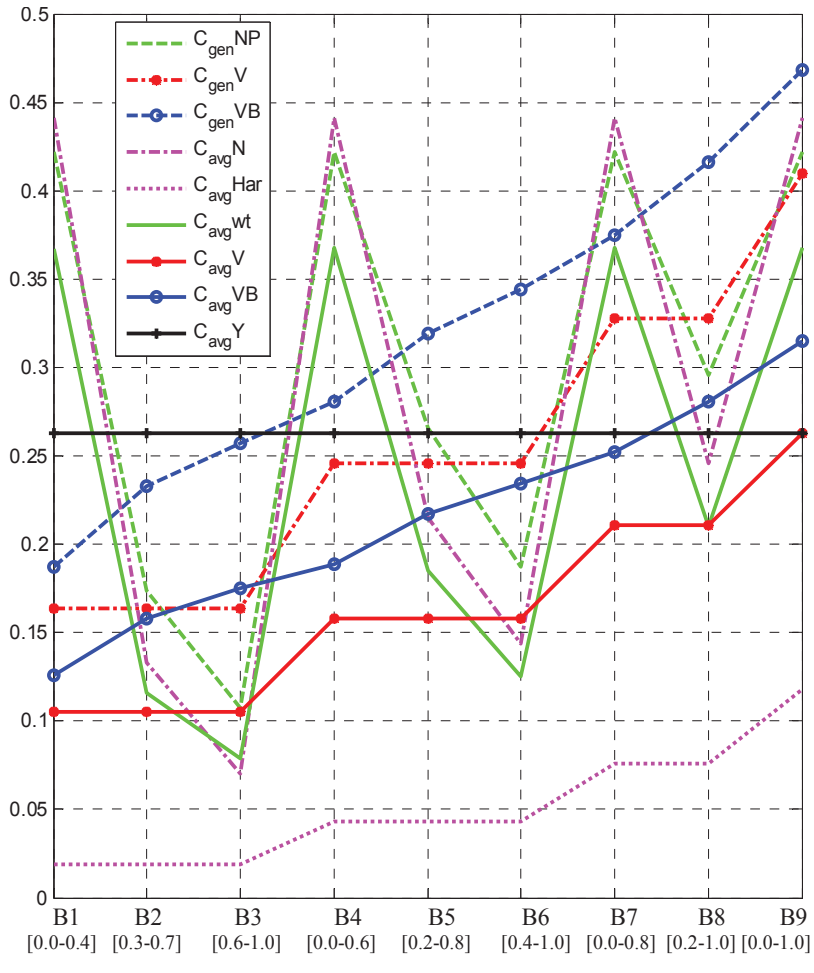

Fig.7. Quantitative assessments for test images B1-B9

Graphs of the values of generalized contrast (Table 4) for standard test images D-N (Fig.5) are shown in Fig.8.

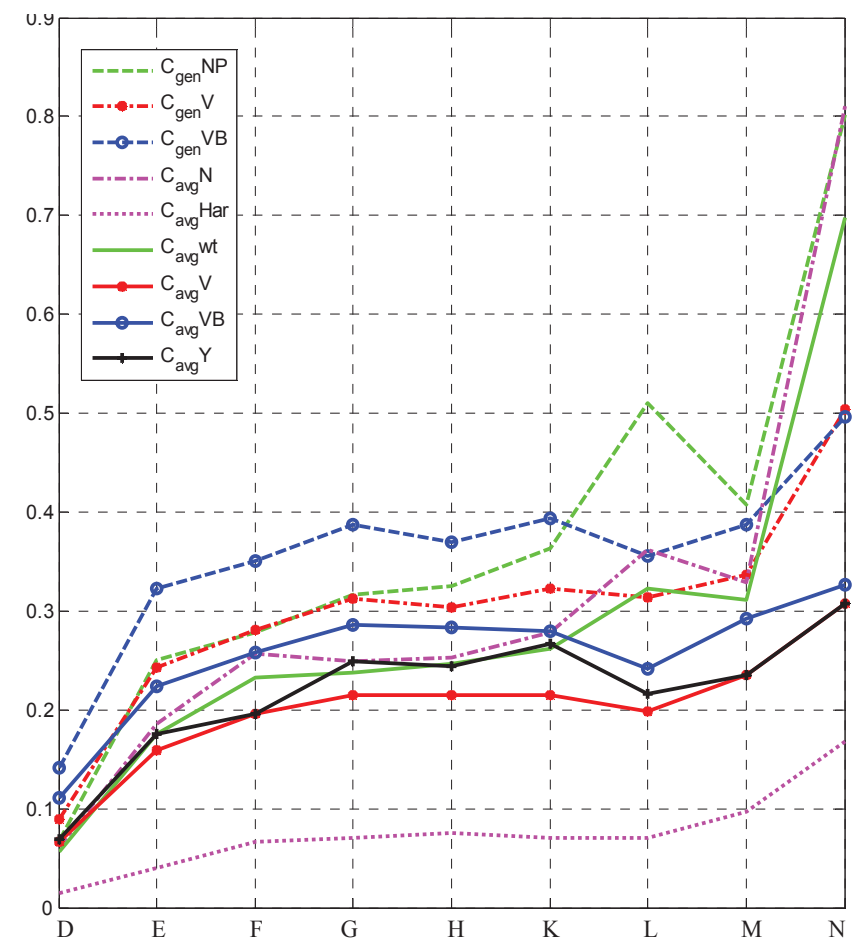

Fig.8. Quantitative assessments for test images D-N

\section{Analysis of the measurements}

Analysis of the results for the test images shows that the assessments (19), (24), (26) based on the kernels (10), (11) of weighted contrast are substantially dependent on the average brightness level of the image and on the additive transformations of brightness of the form $L^{\prime}=L+b$, but are invariant to the multiplicative transformations of the form $L^{\prime}=k \cdot L$.

The assessment (25) based on contrast kernel of Haralick (17) is invariant to additive transformations, but is changed substantially under multiplicative transformations of the image brightness.

The definitions (20), (27) based on linear kernel of Vorobel (14) are invariant to the additive transformations, and are proportional to the multiplicative transformations of image brightness.

Analysis of the results for the test images shows that the assessments (21), (28) based on non-linear kernels of Vorobel\&Beregulyak (15) and of relative contrast (12), (13) are changed substantially under linear transformations of the image brightness.

Analysis of the results for the test images shows that the assessments (19), (20), (21) for the generalized contrast are proportional to the assessments (26), (27), (28) of average generalized contrast of complex images based on local contrast definitions (10), (14), (15), and shows that the assessments (19), (20), (21) give the contrast values that, perhaps, are somewhat overstated.

Definition (29) based on linear kernel of contrast (16) is invariant to linear transformations of image brightness scale.

The assessments of average contrast (27) and (29) for contrast kernel of Vorobel (14) and of linear contrast kernel (16) coincide when analyzing normalized images (when $L_{\min }=0, L_{\max }=L M A X=1$ ).

Analysis of measurement results of generalized contrast for the test images shows that assessments (27), (29) of average contrast based on contrast kernel of Vorobel (14) and of linear kernel (16) are the closest and are most suitable for quantitative assessment of generalized contrast of complex images.

The results of experimental research show that proposed no-reference contrast metrics based on definitions (27), (29) of average contrast of image for the contrast kernels (14), (16) allow providing reasonably accurate quantitative assessment (measurement) of generalized contrast of the real complex images and enable to reasonably evaluate (predict) the perceived image quality at carrying out of subjective (qualitative) expert assessments. 


\section{Conclusions}

In this paper, the problem of no-reference measuring the generalized contrast of complex images was discussed.

Known methods of quantitative assessments of a generalized contrast for complex images based on global histogram have been considered.

The method of quantitative assessment of generalized contrast of complex image based on measuring of the average contrast of image for the various definitions of local contrast of image elements (of contrast kernels) has been proposed.

Comparative analysis of the efficiency of image contrast measurement based on global histogram for the several known and the proposed methods was carried out for a series of complex real and test images.

Analysis of the results of experimental research for real and test images show that no-reference contrast metrics based on a global histogram allow providing accurate measurements (quantitative assessments) of generalized contrast of complex images.

The results of carried out experimental research shows that the known considered assessments of the generalized contrast are proportional to the values of proposed assessments of the average contrast for different known definitions of contrast kernels.

One of the most important problems when measuring of the generalized contrast of complex images is the choice of definition of local contrast for the two elements of image (of definition of contrast kernel).

Analysis of measurement results for the complex real and test images shows that assessments of average generalized contrast for contrast kernel of Vorobel and for contrast kernel which is invariant to the linear transformations are most suitable for a quantitative assessment of the generalized contrast of complex images.

The results of experimental research show that proposed no-reference contrast metrics of the average contrast of image for proposed contrast kernels allow providing reasonably accurate quantitative assessment (measurement) of generalized contrast of the real complex images and enable to reasonably evaluate (predict) the perceived image quality at carrying out of subjective (qualitative) expert assessments.

\section{References}

1. Z. Wang, A. C. Bovik and L. Lu, Why is image quality assessment so difficult? In IEEE International Conference on Acoustics, Speech, and Signal Processing, volume 4, pages IV-3313 -IV-3316, May 2002.
2.Z. Wang and A.C. Bovik, Modern Image Quality Assessment, Morgan and Claypool Publishing Company, New York, 2006.

3. E. Peli (Oct 1990). "Contrast in Complex Images" (PDF). Journal of the Optical Society of America A. 7 (10): 2032-2040. doi:10.1364/JOSAA.7.002032.

4. H. R. Sheikh and A. C. Bovik, "Image information and visual quality", Image Processing, IEEE Transactions on, vol. 15, no. 2, pp. 430-444, 2006.

5. Z. Wang, A. C. Bovik, H. R. Sheikh, and E.P. Simoncelli, Image quality assessment: From error visibility to structural similarity. IEEE Trans. Image Process, 13:600612, 2004.

6. R. C. Gonzalez, R. E.Woods, Digital Image Processing, Prentice Hall, 2002.

7. "Methodology for the subjective assessment of the quality of television pictures", Recommendation ITU-R BT.500-10, 1998.

8. Z. Wang, H. R. Sheikh, A. C. Bovik, B. Furht, O. Marqure, "Objective video quality assessment" in The Handbook of Video Databases: Design and Applications, vol. ch. 41, pp. 1041-1078, Sept 2003, The University of Texas at Austin, CRC Press.

9. M. Shahid, A. Rossholm, B. Lövström, H.-J.Zepernick, No-reference image and video quality assessment: a classification and review of recent approaches, EURASIP Journal on Image and Video Processing, 2014, DOI: 10.1186/1687-5281-2014-40.

10. Z. Wang and A. Bovik, "A universal image quality index", Signal Processing Letters, IEEE, vol. 9, no. 3, pp. 8184, Mar 2002.

11. William K. Pratt Digital Image Processing: PIKS Inside, Third Edition Copyright (C) 2001 John Wiley \& Sons, Inc. ISBNs: 0-471-37407-5.

12. R. Vorobel Image contrast and its connection with fuzzy logic / Roman Vorobel, Olena Berehulyak // Proceedings of IWIM 2007, CTU in Prague. - p.104-110.

13. R. A. Vorobel, The logarithmic image processing / Roman A. Vorobel. - Kyiv: Naukova Dumka, 2012. - 231 p. (The "Science"). - Ref .: s.214-227 - In Ukrainian. I'm from. ISBN 978-966-00-1242-4.

14. Pierre Bouguer. Traité d'optique sur la gradation de la lumière. Paris, 1760.

15. Weber, E. H. (1834, 1996). De tactu. Annotationes anatomicae et physiologicae. Koehler, Leipzig (1834). Transl. H. E. Ross and D. J. Murray (Eds) (1996). E. H. Weber on the Tactile Senses, 2nd edn. Erlbaum (UK), Taylor and Francis, Hove, UK.

16. P.E. King-Smith, J.J. Kulikowski, Pattern and flicker detection analyzed by subthreshold summation, Journal of Physiology, 249, 519-548, (1975).

17. Burkhardt DA, Gottesman J, Kersten D, Legge GE. Symmetry and constancy in the perception of negative and positive luminance contrast, Journal of the Optical Society of America A, 1, 309-316, (1984).

18. P. Whittle, Increments and decrements: luminance discrimination, Vision Res., 26, 1677-1691, (1986). 
19. Sanders, Mark S.; McCormick, Ernest J. (January 1, 1993). Human Factors in Engineering and Design (7th ed.). New York: McGraw-Hill. p. 704. ISBN 978-0070549012.

20. R. A. Vorobel, Digital image processing based on the theory of contrast / Vorobel R. A. The dissertation for the degree of Doctor of Science: 05.13. Lviv, 1999. -369p (In Ukrainian).

21. V. F. Nesteruk, N.N. Porfyryeva, Contrasting law of light perception // Optics and Spectroscopy. - 1970. - vol. XXIX, no. 6. - pp. 1138 - 1143 (In Russian).

22. Vorobel R.A. Perception of the subject images and quantitative evaluation of their contrast based on the linear description of evaluative elements of contrast // Reports of the Ukrainian Academy of Sciences. No.9, pp.103-108, 1998 (In Ukrainian).
23. E.S. Yelmanova Quantitative Assessment of Contrast of the Image Elements // Academic Journals \& Conferences of Lviv Polytechnic National University. Vol 818, No 2015, pp. 69-75 (In Ukrainian).

24. Haralick RM, Shanmuga K, Dinstein / Textural features for image classification. IEEE Transactions on Systems Man and Cybernetics SMC3(6):610 - 621 December 1973.

25. R.M Haralick. Statistical and structural approaches to texture. Proceedings of the IEEE, 67:786-804, 1979.

26. Public-Domain Test Images for Homework's and Projects, http://homepages.cae.wisc.edu/ / /images/

Received in final form on September 16, 2016

Романииин Ю.М., Слманова О.С.

Метод вимірювання без еталону узагальненого контрасту складних зображень на основі гістограми

Проблематика. В наш час вимірювання якості зображень у автоматичному режимі і реальному масштабі часу $€$ надзвичайно актуальним завданням для переважної більшості практичних застосувань обробки зображень. Кількісна оцінка якості зображення без еталону є одним із найбільш актуальних і складних завдань обробки та аналізу зображень.

Узагальнений контраст є найбільш важливою кількісною характеристикою, яка визначає об'єктивну якість зображення в цілому. В наш час одним 3 найбільш актуальних завдань попередньої обробки зображень є розробка нових ефективних методів вимірювання узагальненого контрасту складних зображень у автоматичному режимі 3 рівнем обчислювальних витрат, прийнятним для обробки зображень у режимі реального часу.

Мета досліджень. Розробка методу вимірювання узагальненого контрасту складних (багатоелементних) зображень за їх гістограмою на основі усередненого контрасту елементів зображення (об'єктів і фону) з використанням (для) різних визначень ядра контрасту.

Методика реалізації. Аналіз відомих підходів до вимірювання локального контрасту елементів зображення, відомих методів кількісної оцінки узагальненого контрасту складних зображень, а також результатів експериментальних досліджень для ряду складних реальних і тестових зображень дозволив виявити властиві їм закономірності (відповідність основним вимогам до визначення контрасту, характер і динаміку змін контрасту при лінійних перетвореннях шкали яскравості зображення), які проявляються в залежності від використання різних визначень ядер контрасту і метрик узагальненого контрасту зображень.

Результати досліджень. Запропоновано метрику для вимірювання без еталону узагальненого контрасту складних зображень по їх гістограмі на основі усередненого контрасту елементів зображення для різних визначень ядра контрасту.

Висновки. Запропонована метрика контрасту на основі усередненого контрасту елементів зображення для запропонованих визначень ядер контрасту дозволяє забезпечити точну кількісну оцінку (вимірювання) узагальненого контрасту складних реальних зображень, а також дозволяє досить точно оцінити (прогнозувати) сприйняття якості зображень при проведенні їх суб'єктивних (якісних) експертних оцінок.

Ключові слова: якість зображення; метрика контрасту; вимірювання без еталону; складне зображення; узагальнений контраст; ядро контрасту; гістограма.

Романишин Ю.М., Елманова Е.С.

Метод измерения без эталона обобщенного контраста сложных изображений на основе гистограммы

Проблематика. В настоящее время измерение качества изображений в автоматическом режиме и реальном масштабе времени является чрезвычайно актуальной задача для подавляющего большинства практических приложений обработки изображений. Количественная оценка качества изображения без эталона является одной из наиболее актуальных и сложных задач обработки и анализа изображений. Обобщенный контраст является наиболее важной количественной характеристикой, которая определяет объективное качество изображения в целом. В настоящее время одной из наиболее актуальных задач предварительной обработки изображений является разработка новых эффективных методов измерения обобщенного контраста сложных изображений в автоматическом режиме с уровнем вычислительных затрат, приемлемым для обработки изображений в режиме реального времени. 
Цель исследований. Разработка метода измерения обобщенного контраста сложных (многоэлементных) изображений по их гистограмме на основе усредненного контраста элементов изображения (объектов и фона) с использованием (для) различных определений ядра контраста.

Методика реализации. Анализ известных подходов к измерению локального контраста элементов изображения, известных методов количественной оценки обобщенного контраста сложных изображений, а также результатов экспериментальных исследований для ряда сложных реальных и тестовых изображений позволил выявить присущие закономерности (соответствие основным требованиям к определению контраста, характер и динамику изменений контраста при линейных преобразованиях шкалы яркости изображения), которые проявляются в зависимости от использования различных определений ядер контраста и метрик обобщенного контраста изображений.

Результаты исследований. Предложена метрика для измерений без эталона обобщенного контраста сложных изображений по их гистограмме на основе усредненного контраста элементов изображения для различных определений ядра контраста.

Выводы. Предложенная метрика контраста на основе среднего значения контраста элементов изображения для предложенных определений ядер контраста позволяет обеспечить точную количественную оценку (измерение) обобщенного контраста сложных реальных изображений и позволяет оценить (предсказать) с достаточной точностью воспринимаемое качество изображений при проведении субъективных (качественных) экспертных оценок.

Ключевые слова: качество изображения; метрика контраста; измерения без эталона; сложное изображение; обобщенный контраст; ядро контраста; гистограмма. 